\title{
The Relationship Between Soil Transmitted Helminthes (STH) Infection and Nutritional Status in Students of State Elementary School Number (SDN) 200 Palembang Indonesia
}

\author{
Saraswati Annisa ${ }^{1}$, Dalilah $^{2}$, Chairil Anwar ${ }^{2 \#}$, Novrikasari ${ }^{3}$ \\ ${ }^{1}$ Graduate Student Medical Science, Medical Faculty, Universitas Sriwijaya \\ ${ }^{2}$ Department of Parasitology, Medical Faculty, Universitas Sriwijaya \\ ${ }^{3}$ Faculty of Public Health, Universitas Sriwijaya
}

\# Correspondence: chairil53@yahoo.co.id

Received : February $12^{\text {th }} 2018$

Accepted : March 22 2018

\begin{abstract}
Background: Infection of Soil Transmitted Helminthes (STH) is caused by intestinal nematodes where as in its life cycle, soil is needed as the media for the eggs or larvae to mature into effective forms, most commonly happen to children of school age. This infection is still one of the main problems in public health, including Indonesia. STH infection are widely distributed in tropical and subtropical areas. Lack of personal hygiene, poor environmental sanitation and low socioeconomic status are some factors that plays role in increasing the occurrence of the infection. This infection is also one of the causes responsible for malnutrition in children by decreasing appetite and food intake thus ensued adverse consequences such as declining growth pace, impairment of physical health, and weakening cognitive function. This study was conducted to analyze the association of STH infection with nutritional status of SDN 200 students in Kelurahan Kemas Rindo, Kertapati District, Palembang.

Methods: This study was an analytic observational research with a cross sectional research design. Samples consist of 107 students chosen using proportional stratified random sampling technique. Data was collected by direct interview using questionnaires, measuring body weight and height to obtain nutritional status which then classified using CDC 2000 growth curve while fecal contamination was examined using Kato Katz and modified Harada Mori methode in the Laboratory of Parasitology Medical Faculty of Universitas Sriwijaya. Data then analyzed using Chi-square test.

Results: From 107 students, 27.1\% infection of STH was found on 29 students with 6 students $(20.7 \%)$ infected by A. lumbricoides and 23 students (79.3\%) infected by T. trichiura. Proportion of malnutrition status was found at $43.9 \%$. Statistical test showed a significant association between STH infection and nutritional status $(p=0.036 ; \mathrm{OR}=3.167 ; \mathrm{Cl}$ 95\%: 1.163-15.237).

Conclusion: There was a significant association between STH infection and nutritional status in students of SDN 200 Kelurahan Kemas Rindo Kertapati District Palembang City.
\end{abstract}

Keywords: STH infection, Nutritional status, Analytic observational, Primary students, Palembang city. 


\section{Introduction}

Infectious diseases are still one of the main problems in the world, especially in developing countries like Indonesia, such as infectious intestinal worms. This worm infection is transmitted by soil or known as Soil Transmitted Helminthes (STH). ${ }^{1}$ This disease belongs to the group of Neglected Tropical Diseases (NTD), which is a group of diseases that still occur in many communities but received less attention. ${ }^{2}$ Types of STH worms that often cause infection include Ascaris lumbricoides, Trichuris trichiura, and hookworm (Ancylostoma duodenale dan Necator americanus). ${ }^{3}$

CDC (2013) shows that the estimated population of the world infected by A. lumbricoides ranges from 807 million-1.221 billion people, T. trichiura ranges from 604-795 million people, and hookworms range from 576-740 million people. ${ }^{4}$ The high number of such incidents also occurred in Indonesia. In Indonesia, based on data obtained from the Ministry of Health (2009) on the prevalence of STH infection in 2006 spread in 27 provinces was $42.8 \%$ with most infections caused by $T$. trichiura (24.2\%), A. lumbricoides (17.6\%), and hookworm (1\%). ${ }^{5}$

More than 270 million preschoolers and 600 million school-age children worldwide live in areas with high rates of STH infection. ${ }^{6}$ In South Sumatra, a study conducted on elementary school students in Sukarami Village, Kecamatan Pemulutan, Ogan Ilir District is found in 10\% of worms infected students, with 7\% in boys and 3\% in girls. ${ }^{7}$ Other study at SDN 129 Sematang Borang District Palembang City, which higher is $25.5 \%$ infected by the worms with $15.5 \%$ in boys and $10 \%$ in girls. ${ }^{8}$

Worms infection associated with decreased appetite and food intake that can cause adverse consequences such as declining growth pace, impairment of physical health, decreased activity, weakening cognitive function, to malnutrition in children. ${ }^{9,10}$ Lack of personal hygiene, poor environmental sanitation, low socioeconomic status and high population density are factors contributing to an increase in the incidence of STH infection in primary school students. ${ }^{11}$

Children are the most common people suffering from worm infection, especially primary school-age children because they often play or contact with the soil that grows and develops the worms. The occurrence of worms in primary school-age children can inhibit the growth and development of physical and cognitive that is in a period of rapid and active growth. At this age the child should get balanced nutrition and quality. If this condition get left for long periods of time, the child may suffer from malnutrition, may even become Protein Energy Loss (PEM). This situation causes disruption to the growth and development of children and the deterioration of the quality of life of children, whereas the children are the potential of human resources in the future and is an investment of the nation that will become the successor of this nation's struggle. Thus, it is necessary to conduct research to know the incidence of STH infections in students of SDN 200 Kertapati District Palembang City and its relationship with nutritional status.

\section{Method}

This study was an analytic observational research with a cross sectional research design. This study was conducted in SDN 200 Kertapati District Palembang City and Laboratory of Parasitology Medical Faculty of Universitas Sriwijaya from August to December 2017.

Population in this study was all student of SDN 200, Kertapati District, Palembang City which amounted to 323 students. Samples consist of 107 students who met the inclusion criteria and pass the exclusion criteria, selected by proportional stratified random sampling technique and simple random sampling. 
The dependent variable in this study was nutritional status. The independent variable in this study was age, gender, grade level, parents' occupation, parental education level, parents' income, and STH infection. The data were collected by direct interviews on the subjects using questionnaires, weight and height measurements to obtain nutritional units which were then classified using the CDC 2000 growth curve, and the stool examinations collected were examined using the Kato Katz and modified Harada Mori methods.

\section{Results}

\section{Description of Study Location}

SDN 200 was located at Jalan Meranti Sei Buaya RT 35 RW 8, Kelurahan Kemas Rindo, Kertapati District, Palembang City 30258, with a land area of $6,000 \mathrm{~m}^{2}$. The number of students in this elementary school was 323 students, male students as many as 171 students and female students as many as 152 students. In addition, teachers in this school amounted to 13 teachers and 1 principal. ${ }^{12}$

This school was above the rice field and has 8 classrooms, 1 teacher room, 1 administrative room adjoined to the principal's room, and 3 bathrooms. One classroom was approximately $4 \times 6 \mathrm{~m}^{2}$ in size. Almost all the floors and walls in the classroom were still made of wooden planks, except for 3 classrooms located beside the headroom of the school was tiled and stone-walled. This 3 classrooms were provided shoe rack before the entrance, therefore students were required to remove footwear so as not to contaminate the room. This school did not have a schoolyard, so this school never held a ceremony on Monday. Students exercise by utilizing a small land ground located close to residential residents. This school also did not have a canteen, just there was a small wooden stall on the front when entering the school that used as a place to snack students of this school. Around the school there were still many rice fields, large trees, as well as a vast land area overgrown with shrubs. The road to this school was still in the form of clay and pebbles so that during the rainy season often the road becomes wet and slippery.

\section{Socio-demographic Characteristics of Study Subjects}

Based on Table 1, it can be seen that from 107 subjects examined were mostly aged 8 and 9 years (21.5\% each), more boys (51.4\%) than girls (48.6\%), most subjects came from Third Class (23.4\%), father's occupation from most subjects was farmer/laborer (86.9\%), mother's job from most subjects was housewife $(98.1 \%)$, education level of father or mother most subjects was primary school $(63.6 \%$ and $69.2 \%$ ), and $86.0 \%$ of parents' income subject included in low category. 
Table 1. Distribution of Subjects by Age, Gender, Grade Level, Parents' Occupation, Parents' Education Level, and Parents' Income (n=107)

\begin{tabular}{|c|c|c|}
\hline $\begin{array}{l}\text { Characteristics of } \\
\text { Subjects }\end{array}$ & $\mathbf{n}$ & $\%$ \\
\hline \multicolumn{3}{|l|}{ Age (years) } \\
\hline 6 & 1 & 0.9 \\
\hline 7 & 22 & 11.2 \\
\hline 8 & 23 & 21.5 \\
\hline 9 & 23 & 21.5 \\
\hline 10 & 20 & 18.7 \\
\hline 11 & 13 & 12.1 \\
\hline 12 & 12 & 11.2 \\
\hline 13 & 3 & 2.8 \\
\hline \multicolumn{3}{|l|}{ Gender } \\
\hline Boy & 55 & 51.4 \\
\hline Girl & 52 & 48.6 \\
\hline \multicolumn{3}{|l|}{ Grade Level } \\
\hline II & 24 & 22.4 \\
\hline III & 25 & 23.4 \\
\hline IV & 23 & 21.5 \\
\hline $\mathrm{V}$ & 22 & 20.6 \\
\hline VI & 13 & 12.1 \\
\hline \multicolumn{3}{|l|}{ Father's Occupation } \\
\hline Unemployed & 0 & 0.0 \\
\hline Farmer/Laborer & 93 & 86.9 \\
\hline Enterpreneur & 14 & 13.1 \\
\hline Civil Servant & 0 & 0.0 \\
\hline Etc & 0 & 0.0 \\
\hline \multicolumn{3}{|l|}{ Mother's Occupation } \\
\hline Housewife & 105 & 98.1 \\
\hline Farmer/Laborer & 0 & 0.0 \\
\hline Enterpreneur & 1 & 0.9 \\
\hline Civil Servant & 1 & 0.9 \\
\hline Etc & 0 & 0.0 \\
\hline \multicolumn{3}{|l|}{ Father's Education } \\
\hline \multicolumn{3}{|l|}{ Level } \\
\hline Not Attended & 0 & 0.0 \\
\hline \multicolumn{3}{|l|}{ School } \\
\hline Primary School & 68 & 63.6 \\
\hline Middle School & 26 & 24.3 \\
\hline High School & 13 & 12.1 \\
\hline College/University & 0 & 0.0 \\
\hline \multicolumn{3}{|l|}{ Mother's Education } \\
\hline \multicolumn{3}{|l|}{ Level } \\
\hline Not Attended & 0 & 0.0 \\
\hline \multicolumn{3}{|l|}{ School } \\
\hline Primary School & 74 & 69.2 \\
\hline Middle School & 25 & 23.4 \\
\hline High School & 6 & 5.6 \\
\hline College/University & 2 & 1.9 \\
\hline \multicolumn{3}{|l|}{ Parents' Income } \\
\hline Low & 92 & 86.0 \\
\hline Sufficient & 15 & 14.0 \\
\hline
\end{tabular}




\section{Distribution of STH Infection}

Table 2 showed that from 107 subjects, $27.1 \%$ were infected with STH.

Table 2. Distribution of Subjects by STH Infection $(n=107)$

\begin{tabular}{ccc}
\hline STH Infection & $\mathbf{n}$ & \% \\
\hline Positive (+) & 29 & 27.1 \\
Negative (-) & 78 & 72.9 \\
\hline Total & $\mathbf{1 0 7}$ & $\mathbf{1 0 0 . 0}$ \\
\hline
\end{tabular}

\section{Socio-demographic Characteristics of Positive Subjects Infected with STH}

Table 3 showed that the distribution of positive subjects infected with STH was highest in children aged 8 years at $24.1 \%$. Girls $(51.7 \%)$ were more infected with STH than boys $(48.3 \%)$. Subjects infected with STH were mostly in grade 3 students (27.6\%). Parents' occupation of STH infected subjects was mostly $93.1 \%$ father work as farmer/laborer and $100 \%$ mother as housewife. The last level of education of parents infected subjects STH both father and mother was primary school that is $79.3 \%$ in father and $93.1 \%$ in mother. There were $93.1 \%$ infected subjects whose parents' income included in low category.

Table 3. Distribution of Subjects Infected with STH by Age, Gender, Grade Level, Parents' Occupation, Parents' Education Level, and Parents' Income (n=29)

\begin{tabular}{lrr}
\hline Characteristics of Subjects & n & \% \\
\hline Age (Years) & 1 & \\
6 & 4 & 13.4 \\
7 & 7 & 24.1 \\
8 & 6 & 20.7 \\
9 & 3 & 10.3 \\
10 & 5 & 17.2 \\
11 & 3 & 10.3 \\
12 & & \\
Gender & 14 & 48.3 \\
Boy & 15 & 51.7 \\
Girl & & \\
Grade Level & 7 & 24.1 \\
II & 8 & 27.6 \\
III & 7 & 24.1 \\
IV & 4 & 13.8 \\
V & 3 & 10.3 \\
VI & & \\
Father's Occupation & 0 & 0.0 \\
Unemployed & 27 & 93.1 \\
Farmer/Laborer & 2 & 6.9 \\
Enterpreneur & 0 & 0.0 \\
Civil Servant & 0 & 0.0 \\
Etc & & \\
Mother's Occupation & & \\
Housewife & 29 & 100.0 \\
Farmer/Laborer & 0 & 0.0 \\
Enterpreneur & 0 & 0.0 \\
Civil Servant & 0 & 0.0 \\
Etc & 0 & 0.0 \\
\hline
\end{tabular}




\begin{tabular}{lrr}
\hline $\begin{array}{l}\text { Father's Education } \\
\text { Level }\end{array}$ & & \\
$\quad$ Not Attended & 0 & 0.0 \\
$\quad$ School & & \\
$\quad$ Primary School & 23 & 79.3 \\
$\quad$ Middle School & 4 & 13.8 \\
$\quad$ High School & 2 & 6.9 \\
$\quad$ College/University & 0 & 0.0 \\
Mother's Education & & \\
Level & & \\
$\quad$ Not Attended & 0 & 0.0 \\
$\quad$ School & & \\
$\quad$ Primary School & 27 & 93.1 \\
$\quad$ Middle School & 2 & 6.9 \\
$\quad$ High School & 0 & 0.0 \\
$\quad$ College/University & 0 & 0.0 \\
Parents' Income & & \\
$\quad$ Low & 27 & 93.1 \\
$\quad$ Sufficient & 2 & 6.9 \\
\hline
\end{tabular}

Type of Worm, Number of Worm Eggs, and Intensity of STH Infection in Subjects

Table 4 showed that the most common type of worm that infected the subjects was $T$. trichiura $(79.3 \%)$.

Table 4. Distribution of Subjects Infected with STH by Type of Worm (n=29)

\begin{tabular}{crc}
\hline \multirow{2}{*}{ Type of Worm } & \multicolumn{2}{c}{ STH Infection $(+)$} \\
\cline { 2 - 3 } & n & \% \\
\hline A. lumbricoides & 6 & 20.7 \\
T. trichiura & 23 & 79.3 \\
N. americanus & 0 & 0.0 \\
A. duodenale & 0 & 0.0 \\
S. stercoralis & 0 & 0.0 \\
Trichostrongylus spp. & 0 & 0.0 \\
\hline Total & 29 & 100.0 \\
\hline
\end{tabular}

It was known that the overall intensity of $A$. lumbricoides and $T$. trichiura infections was classified as mild infection, 6 subjects in A. lumbricoides and 23 subjects in T. Trichiura (Table 5).

Table 5. Distribution of Number of Worm Eggs and Intensity of STH Infection (n=29)

\begin{tabular}{ccc}
\hline $\begin{array}{c}\text { Number of Worm } \\
\text { Eggs (Eggs/Gram) }\end{array}$ & $\begin{array}{c}\text { Intensity of } \\
\text { Infection }\end{array}$ & Frequency \\
\hline A. lumbricoides & & \\
440 & Mild & 1 \\
980 & Mild & 1 \\
1960 & Mild & 1 \\
2180 & Mild & 1 \\
2460 & Mild & 1 \\
2520 & Mild & 1 \\
\hline T. trichiura & & \\
20 & Mild & 3 \\
40 & Mild & 1
\end{tabular}




\begin{tabular}{rcc}
60 & Mild & 4 \\
80 & Mild & 9 \\
100 & Mild & 2 \\
180 & Mild & 2 \\
220 & Mild & 1 \\
420 & Mild & 1 \\
\hline Total & & 29 \\
\hline
\end{tabular}

\section{Association between STH Infection and Nutritional Status}

It can be seen that from 29 positive subjects infected with STH most had less nutritional status that's equal to $62.1 \%$. From the statistical test using Chi-square, $p=0.037(\mathrm{p}<0.05)$ and $\mathrm{OR}=2.765$ (95\% CI: 1.147-6.662) so it can be seen that there was statistically significant relationship between STH infection and nutritional status. The OR value of $>2$ indicates that STH infection was a risk factor for poor nutritional status. Students with positive STH infection had a risk of having a nutritional status of less than 2.765 times greater than students with STH-negative infections (Table $6)$.

Table 6. Association between STH Infection and Nutritional Status $(n=107)$

\begin{tabular}{|c|c|c|c|c|c|c|}
\hline \multirow{3}{*}{$\begin{array}{c}\text { STH } \\
\text { Infection }\end{array}$} & \multicolumn{4}{|c|}{ Nutritional Status } & \multirow{2}{*}{\multicolumn{2}{|c|}{ Total }} \\
\hline & \multicolumn{3}{|c|}{ Underweight } & Normal & & \\
\hline & $\mathbf{n}$ & $\%$ & $\mathbf{n}$ & $\%$ & $\mathbf{n}$ & $\%$ \\
\hline$\overline{\text { Infection (+) }}$ & 18 & 62.1 & 11 & 37.9 & 29 & 100 \\
\hline Infection (-) & 29 & 37.2 & 49 & 62.8 & 78 & 100 \\
\hline Total & 47 & 43.9 & 60 & 56.1 & 107 & 100 \\
\hline
\end{tabular}

\section{Discussion}

The differences in the prevalence of STH infection in the studies as well as each of the above areas may be influenced by different risk factors in each study site, particularly those related to environmental sanitation, personal hygiene, age, sex, socioeconomic aspects, a person's level of knowledge, food sanitation, water source sanitation, as well as natural or geographical conditions. ${ }^{14,18,19}$ Playing habits and behavior of children were also influence the rates of STH infections. Often children play and interact directly with the ground, such as not wearing footwear when playing, not washing hands after playing and before eating, and long fingernails make parasites such as Soil Transmitted Helminthes (STH) group easily invade into children's bodies, exacerbated by the environment surrounding the classified as slum and densely populated. ${ }^{16,19}$

In this study, the highest infection was single infection of T. trichiura $(79.3 \%$ of total infected) then followed by single infection of A. lumbricoides (20.7\%), so it can be said that in this study STH infection was dominated by T. trichiura and A. lumbricoides. The results of this study were in line with the results of research from Fauzi et al. (2013) in which T. trichiura infection reached 58,3\% (of total infected), while A. lumbricoides was $25 \%{ }^{20}$ However, different results were found in the results of Juwita's (2013) study, in which A. lumbricoides infection was more common than $T$. trichiura infection. This can be caused by the influence of temperature difference at the research site. The optimum temperature for the development of worm eggs A. lumbricoides and $T$. trichiura was slightly different. T. trichiura eggs will mature at an optimum temperature of $30^{\circ} \mathrm{C}$, 
whereas A. lumbricoides eggs will develop optimally at $25^{\circ}-30^{\circ} \mathrm{C} .{ }^{22}$ In addition, A. lumbricoides infection was easier to treat, resulting in more T. trichiura infection than A. lumbricoides.

Another trigger factor of worm infection is the weather factor. This research was conducted in September to October in Palembang, while in dry season and rainy season which has temperature \pm $30^{\circ} \mathrm{C}$ which is the optimum temperature for T. trichiura egg development. The soil in this study area was moist because the location of this research was experiencing rainy season. The rainy season makes the soil become moist and becomes a supporting factor for the development of worm eggs into infective. ${ }^{18}$ Samuel's study in Ethiopia (2015) found that T. trichiura optimally lives in high humidity, whereas the rates of A. lumbricoides and T. trichiura infections are low in arid regions. ${ }^{23}$

In this study, hookworm (hookworm), strongyloidiasis, and trichostrongylosis were not found. This relates to soil conditions and the number of eggs. A. lumbricoides and T. trichiura require clay soils to develop, while hookworm and S. stercoralis require more loose soil and mixed humus or leaf-covered mud, avoiding direct sunlight, also avoid drying or excessive wet. ${ }^{22}$ The benefit of hookworm prevalence was between $30-50 \%$ in various regions of Indonesia and more common in adults. Higher prevalence was found in plantation areas such as rubber and coffee, and in mining. ${ }^{13}$ The optimum temperature for $N$. americanus was $28-32^{\circ} \mathrm{C}$, while for A. duodenale is slightly lower at $23^{\circ}-25^{\circ} \mathrm{C} .^{22}$ In addition, the development of these worm eggs to become rhabditiform larvae is quite fast ie 24-36 hours for eggs A. lumbricoides and T. trichiura can survive for several years. ${ }^{22,24}$ No infection of $S$. stercoralis and Trichostrongylus spp. in this study, because of these types of worms were rare infect humans. S. stercoralis infection was quite common in primates and dogs, whereas Trichostrongylus spp. more commonly found in herbivorous animals (sheep, goats, camels, and others. ${ }^{25,26}$

The intensity of infection in this study, from 23 subjects infected by trichuriasis and 6 subjects infected by ascariasis, all included mild intensity categories. The category of intensity of this infection was affected by the length and number of worms that infect. The number of worm eggs of STH with the highest degree of mild infection in this study was A. lumbricoides infection which was found to be 2.520 eggs per gram of feces, whereas for T. trichiura was found 420 eggs per gram of feces. Number of eggs produced by 1 female of $A$. lumbricoides was 100,000-200,000 eggs per day while $T$. trichiura can lay as many as 3,000-20,000 eggs per day, so that $A$. lumbricoides eggs will be found in greater quantities than the number of T. trichiura eggs. ${ }^{22}$

In this study, STH infection was highest in children aged 8 years $(24.1 \%)$. The results of this study were similar to studies conducted by Annisa et al. (2017) stating that the prevalence of STH infection wass higher in children aged 6-12 years, and Eryani et al (2015) who stated that the prevalence of STH infection was highest in children aged 6-8 years. ${ }^{27,28}$ The high contamination of worms in this age group was due to the increase of higher playing activity so that the risk of STH infestation was getting bigger. $^{28}$

The result showed that the last education level of the parents of the infected subjects, both father and mother, were $79.3 \%$ and $93.1 \%$, respectively, so the parents' work, especially father was dominant as farmers/laborers, and $93.1 \%$ mother entirely was a housewife. This result in line with previous research on the students of SDN 126 Sematang Borang District Palembang City, it was found that the highest education level of most parents was primary school namely $57.1 \%$ for father and $67.9 \%$ for mother, whereas most father's job was farmer/laborer $(83.6 \%)$ and the mother mostly was a housewife $(80 \%) .{ }^{8}$ Parental education was usually associated with knowledge of hygiene and will affect the growth, development, and establishment of child hygiene practices. Lack of education among the elderly, especially mothers, increases the risk of worm infections in children because parents with high levels of education certainly have better knowledge in terms of clean and healthy life behavior compared with those with low levels of education. If a mother has a good 
education, especially in the health field, will certainly understand healthy life and know how to provide good nutrition for his family. ${ }^{32}$

From 107 subjects, it was found that $43.9 \%$ subjects was underweight. This result was similar to Lesmana et al (2014) in students in SD di Daerah Pesisir Sungai Kecamatan Tapung Kampar District, Riau, obtained $58.16 \%$ of students with good nutritional status and $41,84 \%$ of students with underweight nutritional status. ${ }^{35}$ This was due to the economic level of parents in the school including middle to lower. In general, the parents of students worked as farmers or laborers. Low economic level is one of the factors causing parents can't provide food with balanced nutrition. In addition there are several factors that affect the child's nutritional status, include parental education level, parenting and chronic infections. ${ }^{34,35}$

Male students with underweight nutritional status were $53.2 \%$ and female $46.8 \%$. These results suggest that male students were more likely to have less nutritional status than women. This result was consistent with Nadya's (2016) study which stated that there were more boys (77.8\%) with underweight nutritional status than girls (22.2\%), but not in accordance with Oktapiani (2013) study which stated that there were more girls with underweight nutritional status than boys. ${ }^{7,8}$ Differences in nutritional status between boys and girls may be due to differences in child's physical activity pattern and body tissue network. Generally boys were more active so they need more energy. ${ }^{36}$

Several studies have been conducted to look for an association between nutritional status and STH infection. The relationship was complex and may depend on environmental, social and economic influences. ${ }^{17}$ Between malnutrition and infectious diseases have a very close reciprocity, making it difficult to identify which of these two states come first. ${ }^{16}$ According to Gandahusada (2008) in Ahdal et al (2014), infectious diseases such as worms that affect children can disrupt the child's nutritional status due to several things such as decreased appetite of children due to the discomfort experienced so that nutrient input was reduced, whereas children need more nutrients, especially to replace the body tissue damaged by the disease. ${ }^{16}$

STH infection was also associated with a decrease in dietary consumption, due to the presence of pro-inflammatory cytokines, indigestion and poor nutrient absorption, which can reduce the child's appetite. Infection of $A$. lumbricoides causes mal-absorption of nutrients, because the worms inhibit the absorption of important substances in food in the intestinal lumen. If this condition occurs in chronic form it can lead to inadequate nutrition intake and cause malnutrition, a condition characterized by malnutrition status. Blood loss due to $T$. trichiura infection can lead to chronic dysentery, iron deficiency, iron deficiency anemia and growth disorders. ${ }^{37}$

Low family economic factors can also cause less food intake that children need for growth and development that leads to less nutrition and can result in children susceptible to infectious diseases. ${ }^{38}$ Based on research Harniwita (2008) in Renanti et al (2015) in Desa Buluh Cina Kecamatan Siak Hulu, Kampar District showed there was a correlation between parents' income with nutritional status because in limited economic condition hence fulfillment of nutrition in children was also limited. ${ }^{38}$ According to Sutanto et al (2012) in Renanti et al. (2015), parents' education level especially mother also influenced to child nutrition because the higher of mother education hence expected higher mother's knowledge about health including nutrition so that children get nutritious food. ${ }^{38}$

In this study obtained that all the intensity of the infection included in mild category. Reduced nutritional status due to STH infection often occurs in children with severe infection intensity, but even mild intensity infections may interfere with growth in children with vulnerable nutritional conditions. Simarmata et al. (2015) founds that the intensity of mild to moderate infections may adversely affected the child's nutritional status. ${ }^{17}$ 


\section{Conclusion}

There was a significant correlation between STH infection and nutritional status $(p=0.037$; $\mathrm{OR}=2.765$; 95\% CI: 1.147-6.662) and STH infection variable was a risk factor of underweight nutritional status.

\section{Acknowledgement}

The authors would like to thank the teachers and students of SDN 200 Kertapati District, Palembang City and also staff of Parasitology Department Faculty of Medicine Unversitas Sriwijaya.

\section{References}

1. Mardiana dan Djarismawati. 2008. Prevalensi Cacing Usus pada Murid Sekolah Dasar Wajib Belajar Pelayanan Gerakan Terpadu Pengentasan Kemiskinan Daerah Kumuh di Wilayah DKI Jakarta. Jurnal Ekologi Kesehatan. 7 (2): 769-774.

2. Sudomo, M. 2008. Penyakit Parasitik yang Kurang Diperhatikan di Indonesia. In: Orasi Pengukuhan Profesor Riset Bidang Entomologi dan Moluska. Badan Litbangkes, Jakarta.

3. Noviastuti, A.R. 2015. Infeksi Soil Transmitted Helminths. Majority. 4(8): 107-108.

4. Centers for Disease Control and Prevention (CDC). 2013. Parasites-Soil Transmitted Helminths (STHs) (https://www.cdc.gov/parasites/sth/, diakses 6 Juni 2017).

5. Departemen Kesehatan RI. 2009. Profil Kesehatan Indonesia Tahun 2008. Departemen Kesehatan RI, Jakarta, Indonesia.

6. World Health Organization (WHO). 2017. Soil-Transmitted Helminths Infection. (http://www.who.int/mediacentre/factsheets/fs366/en/, diakses 6 Juni 2017).

7. Oktapiani. 2013. Hubungan Infeksi Soil Transmitted Helminths (STH) dengan Status Gizi pada Siswa Sekolah Dasar di Desa Sukarami Kecamatan Pemulutan Kabupaten Ogan Ilir, Program Studi Kedokteran Universitas Sriwijaya Palembang, 2013. Skripsi pada Universitas Sriwijaya yang tidak dipublikasikan.

8. Nadya, N.N. 2016. Hubungan Infeksi Soil Transmitted Helminths (STH) dengan Status Gizi pada Siswa Sekolah Dasar Negeri 126 Kecamatan Sematang Borang Kota Palembang, Program Studi Kedokteran Universitas Sriwijaya Palembang, 2016. Skripsi pada Universitas Sriwijaya yang tidak dipublikasikan.

9. Ahmed, A., Hesham M.A.M., Abdullah H.A.A., Init I., Awatif M.A., and Johari S. 2012. The Nutritional Impacts of Soil-Transmitted Helminths Infections among Orang Asli School Children in Rural Malaysia. Journal Parasites \& Vector. 5: 119-27.

10. Cabada, M.M., Mary R.G., Brittany G., Pablo G.V.M., Emily L.D., Martha L., Eulogia A., A. Clinton W. 2015. Prevalence of Intestinal Helminths, Anemia and Malnutrition in Paucartambo Peru. Rev Panam Salud Publica. 37(2): 69-75.

11. Shang Y, Lin H.T., Sui S.Z., Ying D.C., Yi C.Y., and Shao X.L. 2010. Stunting and SoilTransmitted-Helminth Infections among School-age Pupils in Rural Areas of Southern China. Journal Parasites \& Vectors. 3: 97.

12. Kementerian Pendidikan dan Kebudayaan. 2017. Data Pokok Pendidikan Dasar dan Menengah: SD Negeri 200 Palembang. (http://dapo.dikdasmen.kemdikbud.go.id/sekolah/7F0FF722C5D481C377D4, diakses 18 November 2017). 
13. Hairani, B., L. Waris, dan Juhairiyah. 2014. Prevalensi Soil Transmitted Helminths (STH) pada Anak Sekolah Dasar di Kecamatan Malinau Kota Kabupaten Malinau Provinsi Kalimantan Timur. Jurnal Buski. 5 (1): 43-48.

14. Faridan, K., L. Marlinae, dan Nelly Al Audhah. 2013. Faktor-Faktor yang Berhubungan dengan Kejadian Kecacingan pada Siswa Sekolah Dasar Negeri Cempaka 1 Kota Banjarbaru. Jurnal Buski. 4 (3): 121-127.

15. Armen. 2012. Kajian Tingkat Infeksi Nematoda Usus pada Murid SDN Nagari Limau Gadang Kabupaten Pesisir Selatan Provinsi Sumatera Barat. Jurnal Sainstek. 4 (1): 84-93.

16. Ahdal, M.T., Saifuddin S., dan Sri'ah Alharini. 2014. Hubungan Infestasi Kecacingan dengan Status Gizi pada Anak SDN Cambaya di Wilayah Pesisir Kota Makassar. (http://repository.unhas.ac.id/bitstream/handle/123456789/10845/MUH.\%20TASBIH\%20AHD AL\%20K11110907.pdf; sequence=1, diakses 19 November 2017).

17. Simarmata, N., Tiangsa Sembiring, dan Muhammad Ali. 2015. Nutritional Status of SoilTransmitted Helminthiasis Infected and Uninfected Children. Pediatrica Indonesiana. 55 (3): 136-140.

18. Wardani, S.K. 2016. Perbandingan Profil Kadar IL-5 dan Jumlah Eosinofil Pada Petani yang Terinfeksi Soil Transmitted Helminth di Dusun Sumberagung Kecamatan Gurah dan Dusun Janti Kecamatan Papar Kabupaten Kediri. Jurnal Biosains. 18 (1): 1-3.

19. Islamudin, R.A., A. Suwandono, L.D Saraswati, dan M. Martini. 2017. Gambaran Perilaku Personal Hygiene yang Berhubungan dengan Infeksi Soil Trasmitted Helminth pada Anak Sekolah Dasar (Studi Kasus di Desa Candi Kecamatan Bandungan Kabupaten Semarang). Jurnal Kesehatan Masyarakat. 5 (1). 212-213.

20. Fauzi, R.R.T., Oki Permana, dan Yulinda F. 2013. Hubungan Kecacingan dengan Status Gizi Siswa Sekolah Dasar di Kecamatan Pelayangan Jambi. Jambi Medical Journal. 1 (1): 1-11.

21. Juwita, Erni. 2013. Hubungan Intensitas Infeksi Soil Transmitted Helminths dengan Status Gizi dan Nilai Rapor pada Anak: Studi Kasus SDN 102052 Bagan Kuala Kabupaten Serdang Bedagai. Magister Ilmu Kedokteran Tropis Fakultas Kedokteran Universitas Sumatera Utara.

22. Supali, T., S.S. Margono dan S.A.N. Abidin. 2008. Nematoda Usus. Dalam: Sutanto, I.S. Ismid, P.K., Sjarifuddin, S. Sungkar (Editor). Parasitologi Kedokteran Edisi Keempat. Balai Penerbit FKUI, Jakarta, hal 4-24.

23. Samuel, Fikresilasie. 2015. Status of Soil-Transmitted Helminths Infection in Ethiopia. American Journal of Health Research. 3 (3): 172-173.

24. Gandahusada, S., H.D. Illahude, dan W. Pribadi. 2008. Parasitologi Kedokteran. Balai Penerbit FK UI, Jakarta, Indonesia.

25. Gunn, A. and Sarah J. Pitt. 2012. Parasitology an Integrated Approach. Wiley-Blackwell, Oxford, UK, pp 114-116, 123-129.

26. Sastry, A.S., Sandhya B.K., and Reba K. 2014. Essentials of Medical Parasitology. Jaypee Brothers Medical Publishers, New Delhi, India, pp 220-247.

27. Annisa, I., Reza D., Dani M.T., Muhammad P.W., Sri W., dan Saleha Sungkar. 2017. Pengaruh Pengobatan Albendazol Dosis Tunggal terhadap Infeksi Soil-Transmitted Helminth dan Status Gizi Anak di Desa Perokonda, Sumba Barat Daya. eJournal Kedokteran Indonesia. 5 (2): 116.

28. Eryani, D., A. Fitriangga, M.I. Kahtan. 2015. Hubungan Personal Hygiene dengan Kontaminasi Telur Soil Transmitted Helminths pada Kuku dan Tangan Siswa SDN 07 Mempawah Hilir Kabupaten Pontianak. Jurnal Mahasiswa PSPD FK Universitas Tanjungpura. 3 (1): 1-15.

29. Derek, C., Angela K., dan Grace K. 2017. Hubungan Antara Faktor Sosiodemografi dengan Infeksi Cacing Usus di SD Negeri 58 Manado. Kesmas. 6 (3): 2-3.

30. Martila, S. Sandy, dan N. Paembonan. 2015. Hubungan Higiene Perorangan dengan Kejadian Kecacingan pada Murid SD Negeri Abe Pantai Jayapura. Jurnal Plasma. 1 (2): 87-96. 
31. Andini, A., Endang S., dan Sofia E.R. 2015. Prevalensi Kecacingan Soil Transmitted Helminths (STH) pada Siswa SDN 1 Kromengan Kabupaten Malang. Jurnal Online Universitas Negeri Malang. 1 (2): 9.

32. Sandy, S., Sri S., dan Soeyoko. 2015. Analisis Model Faktor Risiko yang Mempengaruhi Infeksi Kecacingan yang Ditularkan Melalui Tanah pada Siswa Sekolah Dasar di Distrik Arso Kabupaten Keerom, Papua. Media Litbangkes. 25 (1): 1-14.

33. Saharman, S., Nelly M., dan Rivelino S. Hamel. 2013. Hubungan Personal Hygiene dengan Kecacingan pada Murid Sekolah Dasar di Kabupaten Bolaang Mongondow Utara. Jurnal Keperawatan. 1 (1): 3-7.

34. Anuar, T.S., Fatmah M.S, dan Norhayati M. 2014. Soil-Transmitted Helminth Infections and Associated Risk Factors in Three Orang Asli Tribes in Peninsular Malaysia. Scientific Reports. 4 (4101): 1-7.

35. Lesmana, S.D., Esy M., Lily H., Mislindawati, dan Yossy A. 2014. Hubungan Infestasi Soil Transmitted Helminthes dengan Status Gizi pada Anak SD di Daerah Pesisir Sungai Kecamatan Tapung Kapubaten Kampar, Riau. (http://repository.unri.ac.id/xmlui/bitstream/handle/123456789/7013/penelitian\%202.pdf?seque $\underline{\text { nce }=3}$, diakses 18 November 2017).

36. Suharidewi, I.G.A.T., dan GN Indraguna P. 2017. Gambaran Status Gizi pada Anak TK di Wilayah Kerja UPT Kesmas Blahbatuh II Kabupaten Gianyar tahun 2015. E-Jurnal Medika. 6 (6): 4-5.

37. Darlan, D.M., Tania S.A., and Zaimah Z.T. 2017. Soil Transmitted Helminth Infection in Medan: a-cross sectional study of the correlation between the infection and nutritional status among elementary school children. Family Medicine \& Primary Care Review. 19 (2): 98-103.

38. Renanti, R., Selfi R.R., dan Elmatris S.Y. 2015. Hubungan Infeksi Soil Transmitted Helminth dengan Status Gizi pada Murid SDN 29 Purus Padang. Jurnal Kesehatan Andalas. 4 (2): 353357. 